\title{
Evaluation of High School Students' Perceptions of the Importance of History Lesson and the Students' Achievements
}

\author{
Cansu Soyer, Çağda Kivanç Çağanağa \\ Institute of Graduate Studies and Research, European University of Lefke, Mersin, Turkey \\ Email: cansusoyer@hotmail.com,ckivanc@eul.edu.tr
}

How to cite this paper: Soyer, C. and Çağanağa, Ç.K. (2019) Evaluation of High School Students' Perceptions of the Importance of History Lesson and the Students' Achievements. Open Access Library Journal, 6: e4810.

https://doi.org/10.4236/oalib.1104810

Received: July 30, 2018

Accepted: July 23, 2019

Published: July 26, 2019

Copyright $\odot 2019$ by authors and Open Access Library Inc.

This work is licensed under the Creative

Commons Attribution International

License (CC BY 4.0).

http://creativecommons.org/licenses/by/4.0/

\begin{abstract}
The study is formed in order to investigate and reveal the importance and the acquisitions gained by students through History lesson to the high-school students studying in an institution connected to the Northern Cyprus Education System. In the scope of the subject included in the survey, students studying in 9th and 10th year at Lefkosa Turk High-School were directed questions by using an interview technique of qualitative research method to identify their opinion about the importance and what kind of benefits has provided by History Lesson and several results have been obtained. As a result of the survey, the data received from the opinion of students will reveal the significance of the study.
\end{abstract}

\section{Subject Areas}

Education, History

\section{Keywords}

History, History Education, High School Students, Achievement

\section{Introduction}

The history is embraced as an important part of both social and physical environment of humanity. Whether being conscious or unconscious, it should be known that the experience we had out of our history appears in the background of our emotions, thoughts and behaviour. Everything that forms our current life is formed by the experience we carried from past to present. Depending on previous experiences, the mankind is benefiting from the past in order to shape the future. The history surrounds our lives in a way that we can 
understand and conceive many aspects included in humanity, the physical and social environment of human nature which reserves culture, economy, politics, health, art, sport, geography and literature. "Briefly, history is always with us not because we would like to bear it like poverty but because we cannot escape." History, in other words, is an important subject that helps us interpret the circumstances that take place in our lives and influence the ways we will response to these events [1]. In Turkish Language Association, history is defined as " $\mathrm{a}$ science that examines the circumstances occurred as a result of society, nations and organisational behaviour, explaining these circumstances by pointing date and places, the relationship between the events, how they relate with previous and next events, their interaction and the civilisation formed by each nation" [2].

According to [3], history is defined as a branch of science that investigates community, their war and peace, culture and also their civilisation, and by showing place and date, their social and economic structure within causation depending on documents" [3]. "The meaning of the word history coming from Hebraic VHR origin is story, transferring and explaining" [4]. The definition of history in Western Language is derived from the word "historia" which has the same meaning. This word is expressed as a discipline that subjects and explains the past events. There are many definitions of history. In these definitions, it is interpreted in two ways. The first definition depends on the people lived in the past and social events, where the second definition expresses history as a science that subjects the past history. Covering all these definitions, the scientific assignment of the history is referred as to "search and pass it to future society" [5].

As a lesson, history is the centre of education and teaching. Every nation in the world is trying to teach and develop its own history lesson with specific aims and objectives within the scope of opportunities of their educational system. Education of history expresses that it is impossible for every country and nation to avoid or escape from their past. Therefore, it is important to understand, learn and interpret the current human profile, world's current condition, different communities with all circumstances, and the relationship between the past and present [6].

[7] is defending an opinion of the history teaching is not only about being interested to the past but also requires the assimilation of actual events which ensures to synthesize the future [7]. Like in many educational systems, history lesson that is covered in Turkish Educational System, includes Turkish History and Cyprus Turkish History lessons and both take part in education syllabus. Therefore, it is important to answer the question of "Why we are teaching History?" in order to understand and explain the history education.

As from the second quarter of 20th Century, history educationalists and philosophers have been focused on three main questions; "1) What is history? 2) What does history do? and 3) Why we teach history? These questions and the answers given which are attract the interest of historians everywhere in the world are diversified according to differences shown from person to person [8]. 
According to [9], the answers of "Why we teach history?" stresses the aim of teaching as "the history provides communal incorporation, making students who are studying a well-being citizen and loyal to their nation, helps individuals to comply with life, being conscious about world citizenship as well as contributing to morality" where students could easily access to these behaviours [10].

The first concept that could come up to mind as a memory of nation can be perceived as history. Since a person who had a memory loss because of a car accident and cannot make any decisions or plans for future, the past and present of a nation is related to each other in the same context. Therefore, in order to gain courage from past to take powerful steps towards future shows us the importance of the education of history. This is why history education is accounted as a significant issue. However, like the other subjects included in the syllabus of our educational system, it is also possible to face some problems while teaching history [3]

According to [4], "History lessons take place in a structure of teacher based with simple expression. This is seen as an important factor that students evaluate the lesson as boring and a memorised based subject" [4]. Depending on the teaching techniques of History lessons which create the perception of memorising on students is certainly one of the most important problems of teaching history. This possible situation causes boredom and creates a perception on students that the lesson is memorised based [10].

According to [11], certainly one of the aims of history education is to show the idea that the subject is bored regarding to its descriptive and eclectic structure is actually wrong [11]. The teachers who will teach history should find different methods of how to present the information, thoughts and ideas as well as developing the known educational programmes in order to quit from the boring atmosphere of history education. Generally, history education given within a specific programme at educational institutions aims to help students to gain several information, manner and acquisition about history [11].

The aims of the history education could be defined as adopting national identity based on social-historical context, universalising the ethical and political stance, researching the otherness concept, ensuring sympathy, and beside all these providing different historical analysis and perspectives, and contributing critical thinking at the same time [12].

As a lesson the science of history, aims to teach individuals to think by drawing a contemporary path, questioning and interpretation. It also aims to provide the understanding of social and cultural changes and improvements with integral and critical history intelligence [13].

The other aim is to redound the perspective of multiculturalism to individuals by history education. All the aims and objectives mentioned above are stressed in history books used in the educational system of Northern Cyprus as well as presented as the view of teachers serving. However, these sentences that stress the importance and benefits aimed to provide students are not carried further as 
mentioned and the history subject only takes place within the syllabus as a memorised based lesson that is easily forgotten in the future.

Therefore, today the relevant two sentences formed by the questions of "Why History Lesson is important in education" and "What are the benefits of History lesson for you" exhibits the problems that there is no enough explanation is provided to students based on the context of History lesson, the importance and necessity of the lesson is not clearly delivered, as well as what will students gain after learning history is not declared.

These were the questions that aimed to find the relevant answers in this study. As a result of the study, the answers given to questions were preferable based on the importance and benefit of the lesson. Also the study reveals the significance of the research by measuring to what extent and how the interest and benefits of the lesson is assigned.

\section{Methodology}

In this research qualitative research methods were based and interview technique which is a method of collecting data has been used because of its suitability to the research. In qualitative methods, interviews could be classified as structured, semi-structured and unstructured. Semi-structured questions are designated previously and the data is collected by finding answers to these questions [14].

This method is not really strict as structured interviews and is not flexible as unstructured interviews. Since it provides a flexibility between the options mentioned above which are 2 and 3, semi-structured interview technique has been used for the study.

The study group has been formed through snowball and successive illustration by following the path of purposeful sampling [15]. The main aim of using snowball and successive illustration is that the method is an effective way of finding individuals with necessary information related to the problem as well as measuring the specific occasions since the world is big enough to examine for the study [16].

In this study students studying in a public secondary education institution in Nicosia have been examined. The institution is one of the oldest and well-established schools of education history which is Lefkoşa Türk Lisesi. The school has the largest student potential, recognition and the impression compared to others. Within the school 9th and 10th year students were involved by forming 10 different participatory groups and the teachers and school managements has been excluded from the study. The gender and the class year of the students participated to the study has been presented in Table 1 .

As illustrated in Table 1 within the 10 college students participated to the study the majority of the students involved are 10th year students with a rate of $70 \%$ (7 students). Moreover, the least participation is from 9th year students with a rate of $30 \%$ (3 students). Out of 10 participant students who involved in the survey, 6 of them are female (60\%) and 4 of them are male (40\%). 
Table 1. Distribution of high school students participating in the study according to their grade and gender.

\begin{tabular}{ccccccc}
\hline CLASS & $\begin{array}{c}\text { Number of } \\
\text { Students }\end{array}$ & Percent & $\begin{array}{c}\text { Number of } \\
\text { Female Students }\end{array}$ & Percent & $\begin{array}{c}\text { Number of } \\
\text { Male Students }\end{array}$ & Percent \\
\hline 9. CLASS & 3 Students & $30 \%$ & 1 & $10 \%$ & 2 & $20 \%$ \\
10. CLASS & 7 Students & $70 \%$ & 5 & $50 \%$ & 2 & $20 \%$ \\
TOTAL & 10 Students & $100 \%$ & 6 & $60 \%$ & 4 & $40 \%$ \\
\hline
\end{tabular}

\section{1) Data Collecting Process:}

In this study literature review has been used in order to understand the main problem of the study and evaluate all possible theories that will light up the solutions and all other data gained were collected as a result of the interviews. Survey data were collected between December 2015 and January 2016 by meeting and interview students out of class hours and suitable places chosen by them within the schools. The data collecting process has been completed through 10 15-minute face to face meetings with high-school students where the aim was to learn their opinions about history lesson.

\section{2) Data Collecting Tool:}

The interview forms used during meetings has been designed in different times as a result of the cooperative study of the researcher and several field specialists. The interview questions were prepared for the article survey with a title of "The Evaluation of the Opinions of High-School students about the importance and benefits of History Lesson". Questions were tested by researchers regarding its validity and reliability and used within this survey. The form used to collect data is aimed to identify the importance and benefits of history lesson to high-school student and is designed for students to easily state their opinion about the subject. In order to measure the reliability and validity the forms were given to two different field specialists. As a result, some of the questions were cancelled and taken out from the survey since they were similar, some of the questions were improved regarding its intelligibility and the last shape were given to questionnaire as a result of this inspection.

\section{3) Data Analysis:}

In this study, data collected through the form with two different parts have been resolved by using the method of content analysis. In first part of the form, participants were requested to fill the area which was based on personal information. Then the second part which involves the questions about the study has been resolved by content analysis. In this method data is analysed within four different stages [17].

Data Coding: A meeting document has been formed by designating each line of data gained by writing, as well as recording voices depending on request and resolving them with CDs. The document was given with recorded CDs, notes taken during meetings for analysing any mistakes or drawbacks to a field specialist for ensuring supervision. After forming the interview documents, data 
collected from students were examined and evaluated into groups according to importance, and these groups were named and encoded. A coding list was formed after coding all data, and the list has been a key tool for analysing and arranging the data. Furthermore, coding keys and interview documents were read separately by researchers and necessary arrangements have been made through identifying and discussing the subjects with consensus and dissidence. In order to calculate the reliability of the study, the reliability formula advised by [18] has been used and an average of $90 \%$ result has been achieved. In calculation of reliability, the results over $70 \%$ are accepted as the study is reliable [18]. Therefore, the study with $90 \%$ calculation is accepted as reliable. The codes that relate to each other were aimed as a tool to reach the main themes. In analysing and modelling the study data "QSR Nvivo 8" has been used.

Finding the Themes:

At this stage, codes designated have been categorised under specific topics to form the themes. In the scope of study subject that has been cover in two dimension, different concepts have been found and aligned related to the data under each theme.

Arranging data according to codes and themes:

At this stage, the opinions of participants have been explained clearly for readers to understand easily, and presented directly to the reader. In order to assign which notes are belonging to which participant, footnotes have been used and illustrated within quotation marks. Then the interviewed participants have been mention in brackets.

The coding system given with example explanations below are as follows;

EXAMPLE: “ ." (I:S(A(1)))

I: Interview

S: Student

A: Code of Class Degree

1: Number of Participants

Interpretation of the Findings: The elaborated identification and representation of findings have been commented by the researchers and explanation of some results has been made at this last stage of the study. And the data collected have been interpreted through passing necessary stages of qualitative study method.

\section{Study Results and Interpretation}

In this part of the survey, data collected as a result of the study have been used. Results collected are illustrated in Table 2. In Table 2 depending on the opinion of students to the question of "Why History Lesson is important for you?" the distribution of themes assigned about the importance of the lesson are represented and again in Table 2 depending on the opinion about the question "What are the benefits of History Lesson to students and why it is important?" the distribution of significant themes related to the benefits obtained by history lesson and explanations are submitted. 
Table 2. Concepts of students' opinion about the importance of History lesson.

\begin{tabular}{|c|c|c|c|c|c|}
\hline \multicolumn{6}{|c|}{ STUDENT } \\
\hline \multirow{2}{*}{$\begin{array}{c}\text { THEMES } \\
\text { Time } \\
\text { (Choronology) }\end{array}$} & \multirow{2}{*}{$\begin{array}{c}\begin{array}{c}\text { Number of } \\
\text { Spesific Student }\end{array} \\
8\end{array}$} & \multirow{2}{*}{$\begin{array}{c}\text { Number of } \\
\text { Unknown Student } \\
2\end{array}$} & \multirow{2}{*}{$\begin{array}{c}\text { Total Number of } \\
\text { Student } \\
10\end{array}$} & \multicolumn{2}{|c|}{ Percentage } \\
\hline & & & & 80 & 20 \\
\hline Culture & 6 & 4 & 10 & 60 & 40 \\
\hline $\begin{array}{c}\text { Words } \\
\text { Awareness - Knowing }\end{array}$ & 5 & 5 & 10 & 50 & 50 \\
\hline War & 4 & 6 & 10 & 40 & 60 \\
\hline Thinking & 3 & 7 & 10 & 30 & 70 \\
\hline Other & 2 & 8 & 10 & 20 & 80 \\
\hline
\end{tabular}

\section{1) Students' Opinion about the importance of History Lesson}

One of the most significant factor effecting the success of students regarding the lessons included in their education life is the emotion they develop against the lesson, thoughts and the manner. Therefore, these factors could provide to form the required behaviour of students against the lessons as well as could create difficulties. Because in order to get the required results students should perform positive behaviour.

In this sense, majority of students interviewed have mentioned that history lesson is an important subject for learning the past, illustrated in Table 2. This result with the thoughts and opinion of majority of students participated in the survey reveals that the history lesson is an important subject.

As seen in Table 2, depending on the answers of students through interview forms, some words that are mentioned by students with their own speech have been taken as a base and categorised. $80 \%$ of the students were used the words past and future under the category of Time related to the importance of the lesson. The results reveal that the history lesson is mostly important for learning the past.

Besides this, student's answers proved that they find the lesson important because history "enlightens the future". $60 \%$ of students have been used the words culture and root under the Cultural Category and the results shows that history lesson is determined significant by students in terms of "Learning their Culture and Roots". Under the category of Learning, 50\% of students used the words awareness and knowing which shows that history lesson is important in terms of "being aware of past events, learning the unknown and developing what we know." All other statements appear in the rest categories were slightly used, $40 \%$ of students under the category of War, $30 \%$ under the category of Thinking and $20 \%$ within Other category mentioned that history lesson is important in university entrance exam that reveals the importance of history lesson under each category.

2) Students opinion about acquisitions over History Lesson

In Table 3, several themes have been examined by differentiating them according 
Table 3. Distribution of concepts considered among the achievements of the History Lesson.

\begin{tabular}{cccccc}
\hline \multicolumn{5}{c}{ STUDENTS } \\
\hline THEMES & $\begin{array}{c}\text { Number of } \\
\text { Spesific Students }\end{array}$ & $\begin{array}{c}\text { Number of } \\
\text { Unknown Student }\end{array}$ & $\begin{array}{c}\text { Total Number of } \\
\text { Students }\end{array}$ & Percentage \\
\hline Thinking & 7 & 3 & 10 & 70 & 30 \\
Time & 6 & 4 & 10 & 60 & 40 \\
Knowledge & 5 & 5 & 10 & 50 & 50 \\
Cultural & 2 & 8 & 10 & 20 & 80 \\
Router & 2 & 8 & 10 & 20 & 80 \\
\hline
\end{tabular}

to opinion of students mentioned by their own words through interview form. In this extent, one of the most important subject that forms the base of the study where $70 \%$ student were also mentioned within their thoughts depending on the themes is the "Idea" theme. This theme has been created through the students' expressions of "Perspective", "Criticism", "Analysis" and "Evaluation".

In this sense, students participated have revealed the idea that history lesson provides tremendous acquisitions such as "Developing Perspective", "Ability of Criticism and Showing Criticised Approach", "Analysing Event" and lastly "Evaluation of the Circumstances." Depending on the importance of the lesson $60 \%$ of student opinions were mostly based on the expressions of "Past", "Future" and "Development" that are held under the category of Time Theme and this represented that History is significant in terms of "Teaching the Past", "Contributing to correlate between Past, Present and Future", and also "Developing our current Knowledge".

The expressions of "Consciousness and Knowing" that are held under the theme of Knowledge were frequently used by students and with $50 \%$ rate it created an opinion that history lesson provides important acquisitions such as "History raises awareness of People" and also "Informs People about past life".

Other themes included in the study out of these categories are formed by $20 \%$ of students expressing themselves in similar way which are "Cultural and "Directive" themes. According to the students' opinion these themes that are formed by slightly used expressions have revealed the acquisition gained in different ways. In these themes students mentioned that history lesson contributes them to "To direct their ideas in terms of Politics and Social such as Peace" and in the Cultural context it helps them to "Learn Turkish Race or Cultural Heritage of their Country".

In the scope of the study that covers two dimensions and includes participant's opinions the results gathered virtually have revealed the expected outcome and showed that required answers have been alternately collected. It could be stated that the efficiency of teachers giving history lessons those students who participated in the study is more than expectations and plays an important role. However, it is a known reality that teachers are performing every day the sub- 
jects they aim to teach without delivering the targets, objectives and acquisitions of the lesson to their students while following the necessary education programmes and procedures.

Therefore, it is understood that as a result of examining all participant students' opinions about the importance and benefits of history lesson are gathered around a common sight according to the classes they study.

\section{Conclusions}

To conclude, as a lesson, the Science of History aims to teach individuals to think by drawing a contemporary path, questioning and interpretation, not only with political events, but also aims to provide the understanding of social and cultural changes and the apprehension of collective and critical history through these developments [14].

As a result of this survey, the data collected through the opinion of students that are covered by the information of several studies in the first section of the survey has revealed that the expressions have substantial similarities with aims of the importance and benefits of Science of History as a lesson.

As a science, this lesson is initially necessary for teaching students their past. It is interrogated that students mostly question for what purpose the information learned about History and other subjects in their education and teaching experience will be used in their future life. However, the answer received when asking young and old people why the History lesson is included within our educational system is "Learning Past or our past". Therefore, as a result of information collected, it could be said that History lesson is a significant subject for learning the past. On the other hand, the lesson has other functions that emphasize its importance apart from teaching the past. These functions were emerged through the opinion of students who declared that the history lesson has several objectives, such as "Lightening the Past and the Future" or "Developing a relationship between the Past, Present and the Future". As well as the study of [1], the most significant result of the study is creating time in other words past perception. The idea of that the history is the expression of the past is highly extensive [1]. Besides this, the other most important two ideas are the significance of history in terms of culture, learning and enlightenment. All these opinions of students about the importance of History lesson are corresponding with the assigned borders of intended ideas.

Also for the importance of the subject, related to the acquisitions gained by students, History Lesson aims to help individuals "to think by drawing a contemporary path, questioning and interpreting". With this definition, collecting the intended answers from the majority of 10 participants, several opinions are formed which are related to the aim of the study. Some of the thoughts expressed by students are "Criticising Events, Analysing, and Evaluation". The other two substantial categories have formed chronology and information in terms of time. The data exposed as a result of the study, is providing significant 
information about history lessons given at high-schools depending on the importance and acquisition of the subject. Furthermore, it should be stated that while covering all information mentioned above, it is thought that teachers performing history lessons are able to deliver the necessary information to students.

History education should be designated and remarked according to the conditions and requirements of each period over again. The implementation of these aims and objectives could be possible by providing materials such as books and education programmes which are suitable for these targets and with convenient methods and approaches [8]. It is for sure that teachers delivering ideas about the content and acquisition of the subject both at the beginning of the semester and before the lessons could be efficient. Beside this, it is necessary to rescue students from the idea that the subject is boring and based on a memorising structure in order to provide an effective education and delivering the aims and benefits of history education.

According to [19], several study techniques and methods directed towards efficiency, research and discussion should be used to remove the history from the structure of boring and memorising lesson and therefore a long-term education could be sustained. Also, it is thought the similar unique researches that will be made as thesis and articles could increase the scope of Turkish Education Literature and increase the efficiency of history education [1].

Some of the advices of researchers including several aims about the importance and benefits that could be delivered to students through history lesson which should not just kept in lesson books are as follows:

- At the beginning of each Education Semester for each branch students should be informed conceptually about the importance of history lesson as well as what kind of benefits they will obtain.

- It should be mentioned that history lesson should not be considered only as a whole of historical events and students should be informed that Science of History is a sophisticated lesson that they can also learn information about Politics, Culture, Economy and etc.

- Lastly, teachers should explain students that the History is a science interacting continuously with the Past, Present and the Future, showing this by implementing several methods, techniques and activities and together with students they should improve their knowledge perpetually.

\section{Conflicts of Interest}

The authors declare no conflicts of interest regarding the publication of this paper.

\section{References}

[1] Altun, A. (2014) İlkokul ve ortaokul öğrencilerinin tarih kavramina ilişkin algilarinin yörüngesi. Kuram ve Uygulamada Eğitim Bilimleri, 14, 1-22.

[2] TDK (2016) Tarih. 
http://tdk.gov.tr/index.php?option=com gts\&arama=gts\&guid=TDK.GTS.569d947 $\underline{3679 b 13.62533185}$

[3] Ataş, S.M. (2014) Ortaöğretim Tarih Öğretiminde Karşilaşilan Problemler ve Çözüm Önerileri (Van Örneği). Yüzüncü Yil Üniversitesi, Ortaöğretim Sosyal Alanlar Eğitimi ABD, (Yayimlanmamiş) Yüksek Lisans Tezi, Van.

[4] Akbaba, B. (2003) Tarih öğretiminde fotoğraf kullanimi, Gazi Üniversitesi Ortaöğretim Sosyal Alanlar Anabilim Dali Tarih Öğretmenliği, (Yayimlanmamiş) Yüksek Lisans Tezi, Ankara.

[5] Candan, A.S. and Koçer, Ö. (2013) Tarih dersindeki kavramlarin algilanma düzeylerine ilişkin bir değerlendirme. Tarih Kültür ve Sanat Araştirmalari Dergisi, 1, 353-373. https://doi.org/10.7596/taksad.v2i1.205

[6] Ulusoy, K. (2009) Lise öğrencilerinin tarih dersi sayesinde elde ettiği bazi kazanimlar. Selçuk Üniversitesi Ahmet Keleşoğlu Eğitim Fakültesi Dergisi, 28, 115-134.

[7] Ortaylı, I. (1996) Tarih nedir? Türkiye Günlüğü Dergisi, 39, 152-159.

[8] Aslan, E. (2010) Neden Tarih Öğretiyoruz? Buca Eğitim Fakültesi Dergisi, No. 20.

[9] Ceylan, A. (2012) 11. sinif öğrencilerinin tarih derslerinde akademik tarih dergilerinin kullanimina yönelik görüşleri. Gazi Üniversitesi, Ortaöğretim Sosyal Alanlar Eğitimi Bölümü, (Yayimlanmamiş) Yüksek Lisans Tezi, Ankara.

[10] Güler, I. (2005) Tarihin toplumdaki işlevi ve öğretimi. Istanbul.

[11] Papakis, Y. (2008) Bölünmüş Kibris'ta Tarih Eğitimi: Kibrisli Rum ve Kibrisli Türklerin "Kibris Tarihi” ile Ilgili Ders Kitaplarinin Bir Karşilaştirmasi. PRIO Raporu 2/2008.

[12] Safran, M. (1993) Lise öğretmen ve öğrencilerine göre tarih dersinin amaçlari. Gazi Üniversitesi Eğitim Fakültesi Dergisi, 3, 35-46.

[13] Safran, M. (1993) Tarih öğretiminin eğitimsel amaçlari. Belleten, 220, 827-842.

[14] Karasar, N. (1998) Araştirmalarda Rapor Hazirlama Yöntemi. Pars Matbaacilik Sanayi, Ankara.

[15] Yildirim, A. and Şimşek, H. (2011) Sosyal Bilimlerde Nitel Araştirma Yöntemleri. Seçkin Yayincilik, Ankara.

[16] Barker, B. (2002) Values and Practice: History Teaching 1971-2001. Cambridge Journal of Education, 32, No. 1. https://doi.org/10.1080/03057640220116436

[17] Miles, M.B. and Huberman, A.M. (1994) Qualitative Data Analysis: An Expanded Sourcebook. 2nd Edition, Sage L, California.

[18] Semerci, N. and Özer Ve, B. (2004) Duyuşsal Davranişlarin Kazandirilmasinda Tarih Derslerinin Öğretiminin Önemi (Sözlü Bildiri), XIII. Ulusal Eğitim Bilimleri Kurultayi (06-09 Temmuz 2004). Inönü Üniversitesi Eğitim Fakültesi, Malatya.

[19] Ulusoy, K. (2009) Lise öğrencilerinin tarih dersi sayesinde elde ettiği bazi kazanimlar. Selçuk Üniversitesi Ahmet Keleşoğlu Eğitim Fakültesi Dergisi, 28, 115-134. 